\title{
壁面緑化による夏季の壁面から屋内への熱流および 熱流量の軽減効果
}

The Effect of the Wall Greenery for the Reduction of the Heat Flux and the Accumulated Volume of Heat Flow toward Indoor from the Wall in Summer

\author{
野島 義照* 鈴木 弘孝** \\ Yoshiteru NOJIMA Hirotaka SUZUKI
}

\begin{abstract}
The effect of the wall greenery to reduce the heat flux and the accumulated volume of heat flow toward indoor from the wall for 24 hours in summer was analyzed for 3 different types of buildings where heat flux and other data were measured in the past. The reduction of the heat flux by the wall greenery at the time when the heat flux through the wall without vegetation was maximum were from 84.51 to $13.56 \mathrm{~W}$ (watt) $/ \mathrm{m}^{2}$ and from 96.0 to $61.6 \%$ in ratio. The reduction of the accumulated volume of heat flow for 24 hours were from 1186.79 to $265.52 \mathrm{KJ} / \mathrm{m} 2$ and from 86.4 to $59.3 \%$ in ratio.
\end{abstract}

Keywords: wall greenery, effect, reduction, heat flux, accumulated volume of heat flux キーワード：壁面緑化，効果，軽減，熱流，熱流量

\section{1. 研究の背景と目的}

新しい緑化空間としての屋上緑化は，各種の工法と資材が商品 化され，普及段階に達したといえる。それに対し，壁面緑化はま だ本格的な普及段階に至っては抢らず，特殊な条件が成立した場 合に先駆的に行われている。しかし壁面緑化は歩行者による視認 性が屋上緑化よりも大きく, 都市環境における緑の存在感を演出 する効果が大きいため, 今後一層の普及を図るべき緑化手法であ ると考えられる。

壁面緑化の普及を推進するためには, 如何にして設置および維 持管理のコストを抑えるか，如何にして建築物への荷重負荷を軽 減するか，如何にして適切な維持管理を容易に行えるようにする か，などの課題に対する有効な技術開発を進めると同時に，建築 物の内部の温熱環境の改善, 建築物の外部空間への夏期の熱負荷 の軽減，植栽の葉面加らの水分の蒸散に伴う潜熱消費による都市 のヒートアイランド現象の緩和, 緑の視認による心理的効果など, 壁面緑化が有する各種の効果を数量的に明らかにし，広く国民の 支持が得られるようにすることが重要である。本論文は，壁面緑 化が有する各種の効果のうち建築物内部の温熱環境の改善効果に 着目し，筆頭著者が過去に関わった 3 箇所の異なった構造の建築 物を対象とした計測実験の結果を未発表のデー夕を含め再度分析 し，壁面緑化による夏季の壁面から屋内への熱の流入の軽減効果 を明らかにしようとしたものである。壁面緑化による建築物の温 熱環境の改善効果については, 梅干野らによる報告 $(1985)^{1)}$ が あるが，壁面緑化の方位が西面のみであり，壁面緑化の有無によ る温熱環境の違いが同一時刻で計測されておらず，ナッッ゙タを取 り除いた年の夏に熱環境の計測が行われ，翌年の夏ナッッ゙タが西 壁一面を覆った時に再度熱環境の計測が行われている。松井民憲 $(1990)^{2)}$ は南面に大きなガラス空を設けた建築物を 2 棟作り，そ の前面につる植物によるスダレを置いた場合と置いてない場合と で空調負荷がどれだけ違うかを報告しているが，空面を対象とし て打り壁面が対象とはなっていない。ピチャクムナースら
$(1992)^{3)}$ はビルの西側の壁面で壁面緑化の有無による温熱環境の 違いを報告しているが，日射量と気温の差異のみを扱っている。 一方, 壁面緑化用植物の生育特性については数多くの報告がなさ

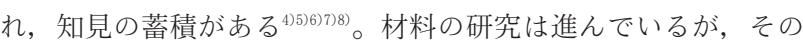
材料を効果的に使用する方法の研究，その材料を使用して壁面緑 化を行った場合にはたしてどのような効果がどの程度期待できる のかについての研究がまだ十分でないと言える。

海外においても，建築物の空調負荷の軽減による省エネルギー 効果等に着目して壁面緑化に関する各種の研究, 報告が活発化し ている ${ }^{910(1) 11122}$ 。

都市内での視認性の高い緑化手法として壁面緑化は効果が大き いが，まだ事例は少ない。壁面緑化パネルを壁面に取り付ける工 法は，設置費用がかかり，毎年維持管理費がかかるため，その実 績は少数にとどまっている。また，自然地盤面に根を張らせたつ る植物で壁面を被覆する従来からの方法は, 初期コス卜も維持管 理コストむ小さいが，放置すると繁茂しすぎて嫌われるという難 点がある。

今後壁面緑化を普及させるためには，コストを低減し魅力度を 向上させる技術開発を進めるとともに，壁面緑化による効果を数 值で明らかにすることが必要である。

本研究では, 壁面緑化による効果の 1 つである夏季の冷房用工 ネルギー使用量の軽減効果がまだ十分には明らかにされていない ため，これを計測事例のデー夕に基づいて解明することを目的之 した。

\section{2. 研究の方法}

\section{(1) 分析の対象}

壁面緑化によりどの程度熱の屋内への流入を抑止する効果があ るのかを明らかにするために，筆頭著者が関わった 3 つの計測事 例を分析の対象とした。この 3 つの事例を対象とした理由は，そ れぞれ構造および建築材料が異なっていおり，かつそれぞれが代

*(株)プレック研究所 ***独立行政法人建築研究所 
表的な建築構造であり，一次的な計測デー夕の使用が可能である ことによる。

事例 1 は合板を使用した簡易プレハブ建築物であるが，建築研 究所の先人が壁面緑化による建築環境の改善効果を研究すること を念頭に置いて設置し，つる植物を植えてあったものである。

事例 2 は鉄筋コンクリート造の 5 階建て集合住宅であり, 所有 者が温熱環境の改善効果を期待してつる植物を意識的に建物に這 わせたあのである。ナッッ゙夕が屋上面にまで達しており，4 階の 南側の壁面を除き, よく建物を覆っている。

事例 3 は, 簡易鉄骨構造の 2 階建て建築物であり, 常緑のッル 植物であるへデラヘリックスのうち葉に白斑が散在し見た感じが 明るい品種（斑入りセイヨウキヅタ）が建物の一部をよく覆って いる。

上記の 3 つの事例における壁面緑化による建築物の温熱環境の 改善効果の計測項目は, 大きく分けて, 気温と表面温度の計測, 熱流の計測, つる植物の葉の表面からの水分の蒸散速度の計測で あった。3つの事例について, 対象とした建築物の概要, 建築物 の所在地, 計測の年月日を以下に示す。

三つの事例は, それぞれ計測結果を発表済みであるが, 壁面か ら屋内への熱流については, 事例 1 及び事例 2 では計測日におけ る経時変化をグラフで示すにとどまっており, 事例 3 では報告し ていない。

事例 $1^{13)}$

\begin{tabular}{|c|c|}
\hline 計測対象建物 & $\begin{array}{l}\text { プレハブ建築の小屋。建設省建築研究所 (当時) } \\
\text { の構内 (つる植物は現存)。壁面緑化植物は、一 } \\
\text { 部でスイカズラが責を覆っていたが、計測部 } \\
\text { 分ではテイカガラ゙優していた。 }\end{array}$ \\
\hline 所在地 & 茨城県つくば市字立原 \\
\hline 計測の年月日 & $\begin{array}{l}1992.07 .30 \sim 07.31 、 1992.08 .04 \sim 08.05 \\
1992.08 .18 \sim 08.19\end{array}$ \\
\hline
\end{tabular}

事(例 $2^{14)}$

\begin{tabular}{|l|l|}
\hline 計測対象建物 & $\begin{array}{l}\text { 鉄筋コンクリート造 5 階建ての事務所併用住宅 } \\
\text { (現在はつる植物は撤去されている)。壁面緑化 } \\
\text { 植物は計測箇所ではナツヅタのみ。 }\end{array}$ \\
\hline 所在地 & 東京都文京区弥生 $2 丁$ 丁目 \\
\hline 計測の年月日 & $1992.08 .14 \sim 08.15$ \\
\hline
\end{tabular}

事(例 $3^{15)}$

\begin{tabular}{|l|l|}
\hline 計測対象建物 & $\begin{array}{l}\text { 軽量鉄骨造 } 2 \text { 階建ての店舗併用住宅。壁面緑化 } \\
\text { 植物は玟入りセイヨウキジタのみ。 }\end{array}$ \\
\hline 所在地 & 茨城県取手市 \\
\hline 計測の年月日 & $1995.08 .24 \sim 08.26$ \\
\hline
\end{tabular}

3 つの事例のそれぞれの状況が端的に理解できる写真を写真 1 〜 3 に示す。

\section{(2) 分析の方法}

各種の計測デー夕のうち, 屋内の冷房負荷に直接関連するデー 夕として壁面の屋内側から屋内への熱流（単位は $\mathrm{W} / \mathrm{m}^{2}$ ) を分 析した。デー夕の記録間隔は, 一部で 30 分であるが, 特に断り がない限り 10 分である。無被覆壁面での〔壁面の屋内側から屋 内への熱流」の最大值に対し, 同時刻の緑化壁面での熱流がどの 程度小さくなっているかを見た。また，24 時間の熱流の積算值 （=熱流量）を計算し, 無被覆壁面での建築物の内部に流入する 日射熱を緑化壁面によってどの程度遮る効果があるかをみた。

\section{3. 分析の結果}

上記の 3 つの計測事例を対象として, つる植物で壁面を覆うこ とによる日射熱の建築物の内部への流入抑制効果を分析した。そ の結果を以下に示す。この場合, 建築物の外壁から内部空間への

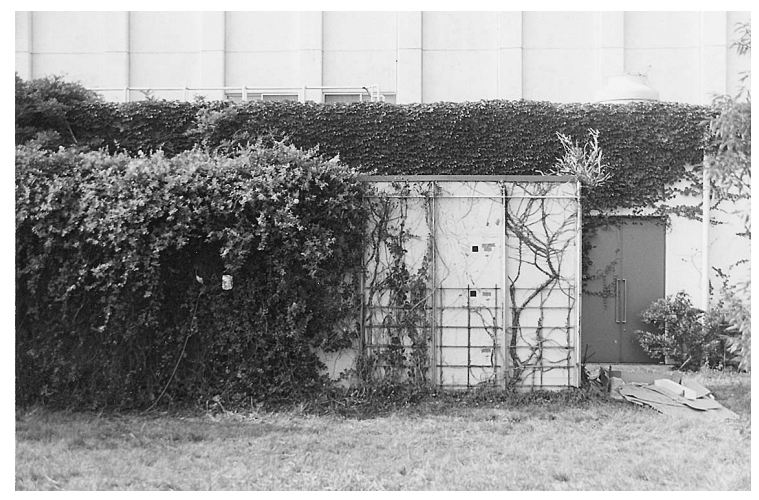

写真一 1 事例 1 の対象となった建築物（当時）

(柱間隔（1 スパン）が $1.82 \mathrm{~m}$ であり, 東端から約 $2.7 \mathrm{~m}$ (1.5 スパン）までの部分で南側の壁面のつる植物を刈り払い, 併せて 東面でもつる植物を刈り払い, 東端側から 1 スパン目までをつる 植物で被覆されていない部分とし, その次の 1 スパンを緩衝ゾー ンとした。)
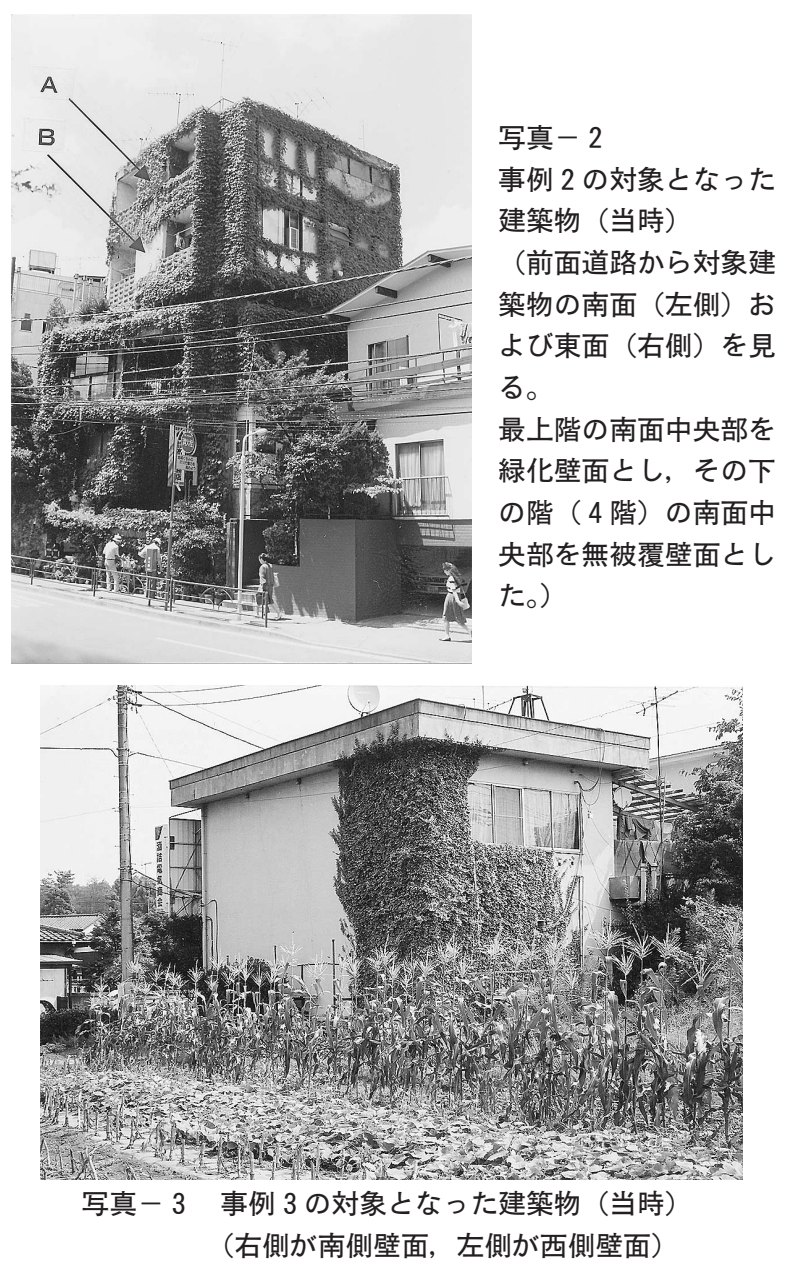

熱の伝わり方に影響を与える要素として, 日中の暑さがどの程度 であったか, 日射の強さがごの程度であったか, 日射を受けて外 壁の温度がどの程度上昇したか, 室内の気温がどうであったか,

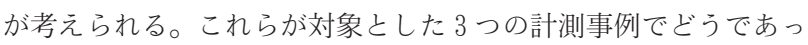
たかを打扔まかに示すために, 熱流の分析対象とした計測日に㧍 けるこれらの要素について, 朝から夜までの毎時の值を整理した ところ, 表 1 ～表 6 のと㧍りであった。

表 2 の観測日は曇天日を対象として計測を行った日であるが, 表 2 以外の観測日は日射が強い真夏日である。 
表－1 事例 1 での各時刻の日射量，気温,外壁表面温度および室内気温 その 1 (1992.7.30)

\begin{tabular}{|c|c|c|c|c|c|c|c|c|c|c|c|c|c|c|c|c|c|}
\hline 時刻 & 05:00 & $06: 00$ & 07:00 & $08: 00$ & 09:00 & 10:00 & 11:00 & 12:00 & $13: 00$ & $14: 00$ & 15:00 & $16: 00$ & $17: 00$ & $18: 00$ & $19: 00$ & $20: 00$ & 21.00 \\
\hline 日射強度 $\left(\mathrm{W} / \mathrm{m}^{2}\right)$ & & & 210.5 & 396.8 & 468.7 & 672.7 & 728.2 & 505.5 & 685.1 & 648.0 & 543.4 & 377.2 & 203.8 & 54.7 & 0.0 & 0.0 & 0.0 \\
\hline 外気温 $\left({ }^{\circ} \mathrm{C}\right.$ ) & & & 27.0 & 29.0 & 30.7 & 32.7 & 33.7 & 33.5 & 34.3 & 34.0 & 34.1 & 32.6 & 31.5 & 30.0 & 28.4 & 26.9 & 26.2 \\
\hline $\begin{array}{l}\text { 外壁表面温度 ( }{ }^{\circ} \mathrm{C} \text { ) } \\
\text { 一段 無被歪繴面 }\end{array}$ & & & & & & 393 & & & & & & & 335 & 307 & 283 & 267 & 256 \\
\hline 下段：被覆壁面 & & & 25.7 & 27.6 & 29.7 & $\begin{array}{l}31.7 \\
31.7\end{array}$ & 33. 4 & $\begin{array}{l}42.9 \\
34.1\end{array}$ & $\begin{array}{l}44.0 \\
34.9\end{array}$ & $\begin{array}{l}42.7 \\
34.9\end{array}$ & $\begin{array}{l}39.9 \\
34.4\end{array}$ & $\begin{array}{l}30.1 \\
33.4\end{array}$ & $\begin{array}{l}33.5 \\
32.3\end{array}$ & $\begin{array}{l}3.1 \\
30.9\end{array}$ & 29.6 & 28.4 & 27.3 \\
\hline 室内気温 $\left({ }^{\circ} \mathrm{C}\right)$ 上段 & & & 25.3 & 27.6 & 30.7 & 34.3 & 37.3 & 38.7 & 39.7 & 39.9 & 38.5 & 36.5 & 34.5 & 32.4 & 30.5 & 28.8 & 27.4 \\
\hline 無被覆 下段: 被覆 & & & 24.7 & 25.8 & 27.4 & 29.1 & 30.7 & 31.9 & 32.7 & 33.2 & 33.1 & 32.6 & 31.9 & 31.0 & 29.9 & 28.8 & 27.8 \\
\hline
\end{tabular}

表－２事例 1 での各時刻の日射量，気温,外壁表面温度および室内気温 その 2 (1992.8.4)

\begin{tabular}{|c|c|c|c|c|c|c|c|c|c|c|c|c|c|c|c|c|c|}
\hline 時刻 & $05: 00$ & $06: 00$ & $07: 00$ & $08: 00$ & $09: 00$ & $10: 00$ & $11: 00$ & $12: 00$ & $13: 00$ & $14: 00$ & $15: 00$ & $16: 00$ & $17: 00$ & $18: 00$ & $19: 00$ & $20: 00$ & 21.00 \\
\hline 日射強度 $\left(\mathrm{W} / \mathrm{m}^{2}\right)$ & 0.0 & 120.8 & 251.2 & 347.3 & 462.3 & 844.7 & 518.8 & 845.8 & 722.3 & 510.0 & 636.0 & 375.3 & 213.8 & 0.0 & 0.0 & 0.0 & 0.0 \\
\hline 外気温 $\left({ }^{\circ} \mathrm{C}\right)$ & 22.7 & 24.3 & 25.7 & 26.1 & 27.3 & 29.1 & 29.4 & 30.2 & 30.9 & 30.6 & 30.8 & 29.9 & 28.8 & 27.2 & 25.9 & 25.1 & 24.5 \\
\hline 外壁表面温度 $\left({ }^{\circ} \mathrm{C}\right)$ & & & & & & & & & & & & & & & & & \\
\hline 上段：無被覆壁面 & 21.3 & 22.9 & 25.4 & 27.9 & 30.0 & 39.9 & 34.4 & 41.0 & 37.9 & 38.1 & 36.2 & 30.5 & 27.8 & 25.7 & 23.9 & 23. 1 & 22.8 \\
\hline 下段：被覆壁面 & 22.7 & 23.3 & 24.9 & 26.1 & 26.9 & 29.9 & 29.4 & 30.8 & 30.8 & 30.4 & 29.8 & 28.7 & 27.2 & 26.0 & 24.9 & 24.4 & 24.1 \\
\hline 室内気温 $\left({ }^{\circ} \mathrm{C}\right)$ 上段: & 21.8 & 22.1 & 23.2 & 24.1 & 24.8 & 26.2 & 26.6 & 27.5 & 27.5 & 27.4 & 27.1 & 25.0 & 23.6 & 23.7 & 23.4 & 23.4 & 23.7 \\
\hline 無被覆 下段: 被覆 & 21.3 & 21.5 & 22.5 & 23. 3 & 24.0 & 25.0 & 25.3 & 26.1 & 26.6 & 27.0 & 26.9 & 24.7 & 23.0 & 23.0 & 22.8 & 22.9 & 23.5 \\
\hline
\end{tabular}

表－3 事例 1 での各時刻の日射量，気温,外壁表面温度および室内気温 その 3 （1992.8.18）

\begin{tabular}{|c|c|c|c|c|c|c|c|c|c|c|c|c|c|c|c|c|c|}
\hline 時刻 & $05: 00$ & $06: 00$ & $07: 00$ & $08: 00$ & $09: 00$ & $10: 00$ & $11: 00$ & $12: 00$ & $13: 00$ & $14: 00$ & $15: 00$ & $16: 00$ & $17: 00$ & $18: 00$ & 19:00 & $20: 00$ & 21.00 \\
\hline 日射強度 $\left(\mathrm{W} / \mathrm{m}^{2}\right)$ & & & & & 643.8 & 481.6 & 380.9 & 1019.7 & 953.4 & 742.1 & 292.4 & 452.1 & 206.4 & 66.3 & 0.0 & 0.0 & 0.0 \\
\hline 外気温 $\left({ }^{\circ} \mathrm{C}\right)$ & & & & & 29.8 & 30.6 & 30.8 & 30.5 & 31.8 & 32.4 & 30.7 & 30.1 & 29.3 & 28.6 & 27.9 & 27.5 & 26.7 \\
\hline $\begin{array}{l}\text { 外壁表面温度 ( }{ }^{\circ} \mathrm{C} \\
\text { 上段: 無被覆壁面 }\end{array}$ & & & & & 34.9 & 35.2 & 34.5 & 37.0 & 36.5 & 33.8 & 33.0 & 32.0 & 31.1 & 30.1 & 29.4 & 28.7 & 28.0 \\
\hline 下段：被覆壁面 & & & & & 28.6 & 29.1 & 29.6 & 30.3 & 30.9 & 30.8 & 30.6 & 30.4 & 30.1 & 29.7 & 29.4 & 29.1 & 28.5 \\
\hline 室内気温 $\left({ }^{\circ} \mathrm{C}\right)$ 上段 & & & & & 28.2 & 28.8 & 29.4 & 29.9 & 30.4 & 30.2 & 30.2 & 30.1 & 29.9 & 29.7 & 29.5 & 29.3 & 29.0 \\
\hline 無被覆 下段：被覆 & & & & & 27.6 & 28.0 & 28.4 & 28.8 & 29.4 & 29.5 & 29.8 & 29.8 & 29.9 & 29.9 & 29.7 & 29.7 & 29.3 \\
\hline
\end{tabular}

表 -4 事例 2 での各時刻の日射量，気温,外壁表面温度および室内気温（1992.8.14）

\begin{tabular}{|c|c|c|c|c|c|c|c|c|c|c|c|c|c|c|c|c|c|}
\hline 時刻 & $05: 00$ & $06: 00$ & 07:00 & $08: 00$ & $09: 00$ & $10: 00$ & $11: 00$ & $12: 00$ & $13: 00$ & $14: 00$ & $15: 00$ & $16: 00$ & $17: 00$ & $18: 00$ & $19: 00$ & $20: 00$ & 21.00 \\
\hline 日射強度 $\left(\mathrm{W} / \mathrm{m}^{2}\right)$ & 0.0 & 100.0 & 279.1 & 472.1 & 620.9 & 837.2 & 465.1 & 660.5 & 688.4 & 539.5 & 567.4 & 207.0 & 148.8 & 0.0 & 0.0 & 0.0 & 0.0 \\
\hline 外気温 $\left({ }^{\circ} \mathrm{C}\right)$ & 24.5 & 25.9 & 27.2 & 28.9 & 29.9 & 33.3 & 34.6 & 34.5 & 35.2 & 36.5 & 34.7 & 34.5 & 31.7 & 29.7 & 28.5 & 27.8 & 27.4 \\
\hline 外壁表面温度 $\left({ }^{\circ} \mathrm{C}\right)$ & & & & & & & & & & & & & & & & & \\
\hline 上段：無被覆壁面 & 24. 4 & 25.82 & 26.4 & 27.9 & 29.6 & 31.4 & 33.9 & 35.4 & 36.8 & 42. 2 & 48. 1 & 47.9 & 41.5 & 33.6 & 29.7 & 28.1 & 27.1 \\
\hline 中段：薄く被覆 & 25.4 & 25.8 & 26.5 & 27.4 & 26.3 & 29.4 & 30.8 & 31.8 & 32.6 & 35.1 & 38.7 & 40.6 & 38.9 & 32.8 & 30.6 & 29.4 & 28.5 \\
\hline 下段 : 厚 (被覆) & 26.2 & 26.3 & 26.5 & 27.0 & 27.6 & 28. 3 & 29.2 & 29.8 & 30.4 & 31.4 & 32.8 & 33.9 & 33. 3 & 31.3 & 30.2 & 29.4 & 28. 8 \\
\hline 室内気温 & \multicolumn{17}{|c|}{ 測定しなかった。計測した壁面は I 階店舗の西側であり、店舗は日中は冷房が作動していた。 } \\
\hline
\end{tabular}

表－ 5 事例 3 での各時刻の日射量，気温，外壁表面温度および室内気温 その 1 (1995.8.25)

\begin{tabular}{|c|c|c|c|c|c|c|c|c|c|c|c|c|c|c|c|c|c|}
\hline 時刻 & 05:00 & $06: 00$ & $07: 00$ & $08: 00$ & $09: 00$ & $10: 00$ & $11: 00$ & $12: 00$ & $13: 00$ & $14: 00$ & $15: 00$ & $16: 00$ & $17: 00$ & $18: 00$ & $19: 00$ & $20: 00$ & 21.00 \\
\hline 日射強度 $\left(\mathrm{W} / \mathrm{m}^{2}\right)$ & 0.0 & 19.2 & 42.3 & 142.8 & 274.3 & 602.0 & 573.2 & 764.2 & 441.7 & 429.8 & 270.3 & 232.2 & 205.7 & 31.3 & 0.0 & 0.0 & 0.0 \\
\hline 外気温 $\left({ }^{\circ} \mathrm{C}\right)$ & 19.6 & 19.7 & 19.9 & 0.7 & 1.6 & 23.8 & 24.0 & 25.1 & 23.9 & 22.3 & 22.1 & 21.0 & 20.1 & 9.9 & 19.8 & 19.8 & 19.8 \\
\hline 外壁表面温 & & & & & & & & & & & & & & & & & \\
\hline 上段: 無被覆壁面 & 18. 9 & 19. 3 & 19. 8 & 21.7 & 24. 0 & 28.7 & 29.9 & 34.9 & 30.8 & 30.8 & 27.4 & 27.0 & 25.4 & 22. 3 & 20.5 & 19. 9 & 19.6 \\
\hline 下段：被覆壁面 & 19.5 & 19.6 & 19.7 & 20.4 & 21.1 & 23.0 & 24. 1 & 25.7 & 25.4 & 25.1 & 24.0 & 23.6 & 23.2 & 22.0 & 21.0 & 20.5 & 20.1 \\
\hline 室内気温 $\left({ }^{\circ} \mathrm{C}\right)$ 上段: & 19.4 & 19.5 & 19.8 & 20.6 & 21.8 & 24.4 & 26.7 & 29.4 & 29.6 & 28.7 & 27.3 & 26.6 & 25.7 & 23.9 & 22.3 & 21.2 & 20.6 \\
\hline 無被覆 下段：被覆 & 19.5 & 19.6 & 19. 7 & 19.9 & 20.4 & 21.4 & 22.6 & 23.7 & 24.4 & 24.3 & 23.8 & 23.4 & 23.1 & 22.4 & 21.6 & 21.0 & 20.6 \\
\hline
\end{tabular}

表－６事例 3 での各時刻の日射量，気温，外壁表面温度および室内気温 その 2 （1995.8.26）

\begin{tabular}{|c|c|c|c|c|c|c|c|c|c|c|c|c|c|c|c|}
\hline 時刻 & $05: 00$ & $06: 00$ & $07: 00$ & 08:00 & $09: 00$ & $10: 00$ & $11: 00$ & $12: 00$ & $13: 00$ & $14: 00$ & $15: 00$ & $16: 00$ & $17: 00$ & $18: 00$ & $19: 00$ \\
\hline 日射強度 $\left(\mathrm{W} / \mathrm{m}^{2}\right)$ & 0.0 & 69.8 & 341.9 & 523.3 & 695.3 & 867.4 & 755.8 & 788.4 & 751.2 & 537.2 & 465.1 & 276.7 & 153.5 & 0.0 & 0.0 \\
\hline 外気温 $\left({ }^{\circ} \mathrm{C}\right)$ & 23.9 & 24.6 & 26.5 & 28.4 & 30.5 & 34.2 & 33.6 & 36.8 & 39.3 & 38.7 & 37.1 & 34.9 & 32.7 & 30.8 & 39.3 \\
\hline 外壁表面温度 $\left({ }^{\circ} \mathrm{C}\right)$ & & & & & & & & & & & & & & & \\
\hline 上段：無被覆壁面 & 23.9 & 24.3 & 25.8 & 27.6 & 29.6 & 31.6 & 33.2 & 35.2 & 37.3 & 42.7 & 46.7 & 47.0 & 42.9 & 34.8 & 30.8 \\
\hline 中段：薄く被覆 & 25.0 & 25.1 & 25.9 & 26.9 & 28.1 & 29.3 & 30.1 & 31.5 & 32.4 & 35.0 & 39.8 & 41.0 & 37.9 & 33.2 & 30.9 \\
\hline 下段：厚〈被覆） & 25.9 & 25.7 & 26.1 & 26.6 & 27.4 & 28.1 & 28.8 & 29.5 & 30.2 & 31.2 & 32.5 & 33.5 & 33.4 & 31.5 & 30.4 \\
\hline 室内気温 & \multicolumn{15}{|c|}{ 測定しなかった。計測した壁面は I 階店舗の西側であり、店舗は日中は冷房が作動していた。 } \\
\hline
\end{tabular}

（1）事例 1 (プレハブ建築の小屋）の場合（南側壁面）

壁面の構造は，化粧石綿セメント板（厚さ $4.7 \mathrm{~mm}$ ) である。

(i ) 晴天日 (冷房なし)

1992 年 7 月 30 日（木）(晴天日） $5 ： 00 \sim 7$ 月 31 日（金） 8 ：
00 までの南側壁面での熱流（上，中，各 1 ポイントの平均值） の経時変化をグラフで示すと図 1 のと打りであった。屋内に向か う熱流はマイナスの数值で表した（グラフ上で熱流を示す線が下 に向かうほど屋内に多くの熱が流入していることになる）。 


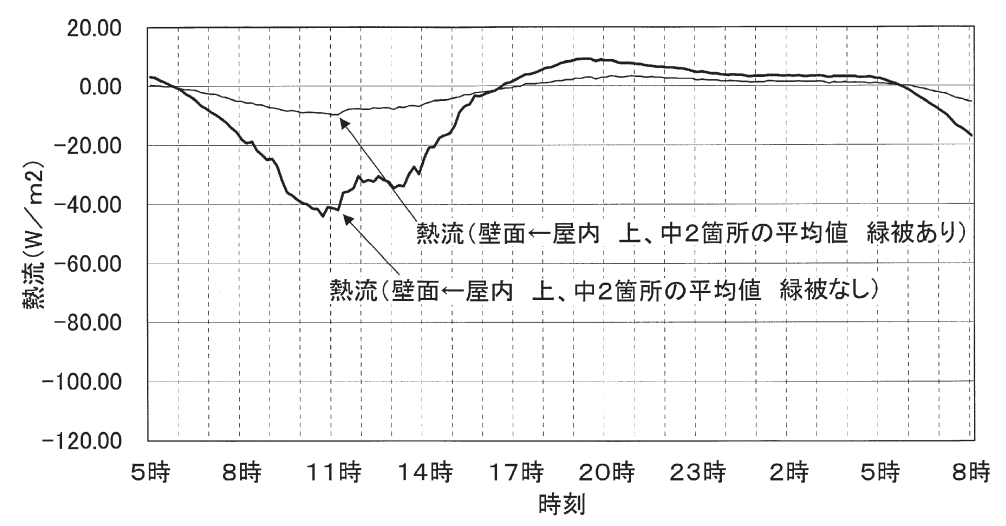

図－1 南側壁面から屋内へ流入する熱流の経時変化 （事例 1 (プレハブ建 築の小屋) の場合。晴天日。冷房なし）

（1992 年 7 月 30 日（木）（晴天日）～ 7 月 31 日(金） 無被覆壁面の 屋内空間と緑化壁面の屋内空間とを断熱材で分離区画)

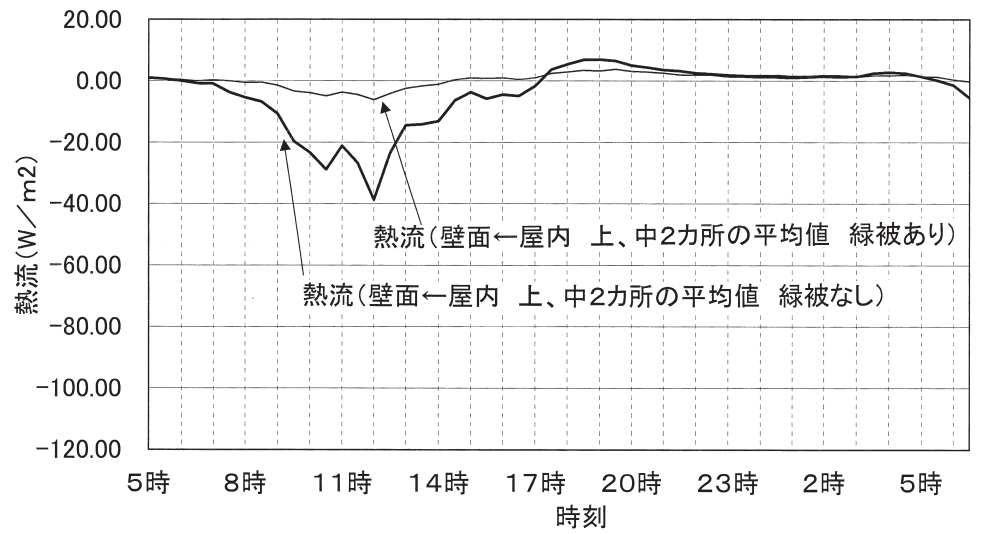

図－２南側壁面から屋内へ流入する熱流の経時変化（事例 1 (プレハブ建築 の小屋) の場合。量天日。冷房なし)

(1992 年 8 月 4 日 (火) (曇天日) 8 月 5 日 (水) 間と緑化壁面の屋内空間とを断熱材で分離区画)

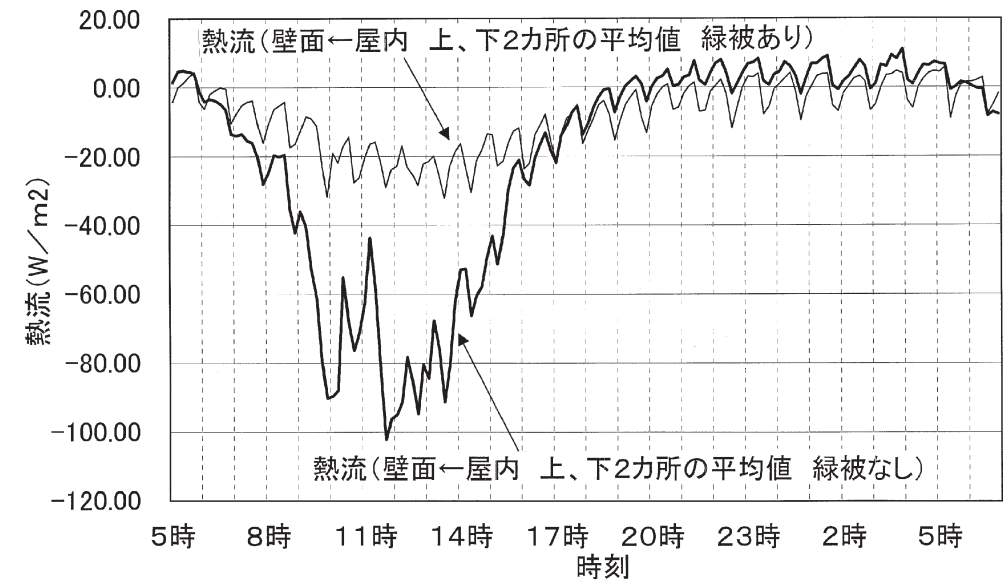

図－3 南側壁面から屋内へ流入する熱流の経時変化 （事例 1 （プレハブ建築 の小屋）の場合。晴天日。冷房あり）

（1992 年 8 月 18 日（火）（晴天日）～８月19日（木） 断熱材による分 離区画を撤去)

壁面から屋内への熱流は無被覆壁面では 10：40 に最大値 $44.01 \mathrm{~W} / \mathrm{m}^{2}$ を記録した。同じ時刻に緑化壁面での熱流は 9.15W/ m²゙あり，無被覆壁面の $20.8 \%$ であった。
熱流を積算した熱流量は，屋内側への流入熱量 のみを 7 月 30 日 5：00〜 7 月 31 日 5：00まで の 24 時間值で見ると, 無被覆壁面では $858.57 \mathrm{KJ}$ / m²であったのに対し, 緑化壁面では $219.88 \mathrm{KJ} /$ $\mathrm{m}^{2}$ であり，無被覆壁面の $25.6 \%$ であった。

（ii）曇天日（冷房なし） 1992 年 8 月 4 日 （火）（曇天日） $5 ： 00 \sim 8$ 月 5 日（水） $6: 30$ までの南側壁面での熱流（上，中，各 1 ポイント の平均値）の経時変化をグラフで示すと図 2 のと おりであった。

30 分間隔で計測しているため, 精度が落ちる が，以下に示すように，壁面から屋内への熱流は 無被覆壁面では $12 ： 00$ に最大值 $38.73 \mathrm{~W} / \mathrm{m}^{2}$ を 記録した。同じ時刻に緑化壁面での熱流は 6.16 $\mathrm{W} / \mathrm{m}^{2}$ であり，無被覆壁面の $15.9 \%$ であった。熱 流を積算した熱流量は，屋内側への流入熱量のみ を 8 月 4 日 $5 ： 00 \sim 8$ 月 5 日 $5 ： 00$ までの 24 時 間值で見ると，無被覆壁面では $499.85 \mathrm{KJ} / \mathrm{m}^{2}$ であっ たが，緑化壁面では $67.78 \mathrm{KJ} / \mathrm{m}^{2}$ であり，無被覆 壁面の $13.6 \%$ であった。

（iii）晴天日（冷房あり）1992 年 8 月 18 日（火） （晴天日） $5 ： 00 \sim 8$ 月 19 日（木） $6 ： 50$ まで の南側壁面での熱流（上，中，各 1 ポイントの平 均值）の経時変化をグラフで示すと図 3 のとおり であった。断熱材による区画を除去し，冷房を稼 働させ, 屋内の気温は無被覆壁面でも緑化壁面で あ同じにした。冷房は，サーモスタットにより， 暑くなると作動し，室温がある程度下がるとストッ プした。壁面から室内への熱流は無被覆壁面では 11 ：40 に最大值 $102.29 \mathrm{~W} / \mathrm{m}^{2}$ を記録した。同じ時

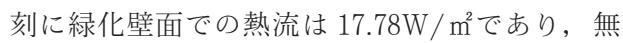
被覆壁面の $17.4 \%$ であった。

熱流を積算した熱流量は, 屋内側への流入熱量 のみを 8 月 18 日 $5 ： 00 〜 8$ 月 19 日 5：00 まで の 24 時間值で見ると，無被覆壁面では $1999.77 \mathrm{~K}$ $\mathrm{J} / \mathrm{m}^{2}$ であったが，緑化壁面では $812.98 \mathrm{KJ} / \mathrm{m}^{2}$ で あり，無被覆壁面の $40.7 \%$ あったた。

（2）事例 2 （鉄筋コンクリート造）の場合（南 側壁面）

建物南面の最上階（５階）中央部の緑化壁面之 4 階中央部の無被覆壁面で熱流を計測した。計測 ポイントは写真で矢印を付けた部分である。A を緑化壁面，B を無被覆壁面とした。Aの部分 も B の部分も,この裹は物置スペースとなって おり冷房はできない。壁面の構造は，鉄筋コンク リート打ちっ放し (厚さ $150 \mathrm{~mm}$ ) である。

1992 年 8 月 14 日（金）（晴天日） $5: 00 \sim 8$ 月 15 日（土） $9 ： 20$ までの南側壁面での熱流 （中央で 1 ポイントのみ計測）の経時変化をグラ フで示すと図 4 のと打りであった。

壁面から屋内への熱流は無被覆壁面では 13 : 20 に最大值 $26.40 \mathrm{~W} / \mathrm{m}^{2}$ を記録した。同じ時刻に 緑化壁面での熱流は $1.05 \mathrm{~W} / \mathrm{m}^{2}$ であり，無被覆壁 面の $4.0 \%$ でった。

熱流を積算した熱流量は, 屋内側への流入熱量 のみを 8 月 14 日 8：20（コンセントから外れていたデー夕記録 装置の差し込みプラグを再びコンセントに差し込んだ後の測定時 刻） 8 月 15 日 


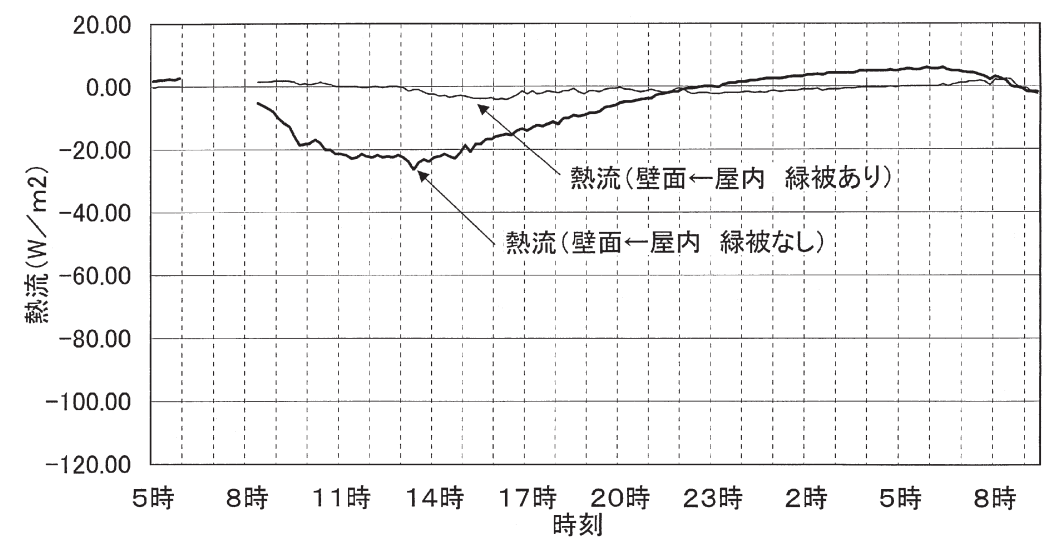

図－4 南側壁面から室内へ流入する熱流の経時変化 （事例 2（鉄筋コンクリー 卜造）の場合。晴天日。冷房なし)

（1992 年 8 月 14 日(金)（晴天日）～8 月 15 日(土))

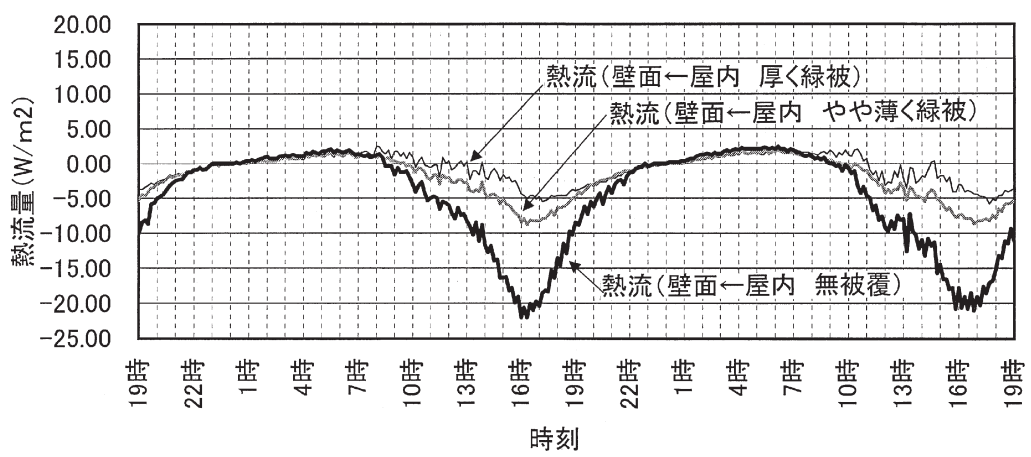

図－５西側壁面から室内へ流入する熱流の経時変化（事例 3 (軽量鉄骨造）の 場合。晴天日。西側壁面。冷房あり)

(1995 年 8 月 24 日 (木) (晴天日) 8 月 26 日 (土))

$16: 20$ には $8.80 \mathrm{~W} / \mathrm{m}^{2}, 8$ 月 26 日 $16: 50$ には $8.63 \mathrm{~W} / \mathrm{m}^{2}$ であり, 平均すると無被覆壁面の $39.7 \%$ でった。

$8: 20$ までの 24 時間値で見ると, 無被覆壁面では $715.90 \mathrm{KJ} / \mathrm{m}^{2}$ であったが, 緑化壁面では $100.54 \mathrm{KJ} / \mathrm{m}^{2}$ ありり, 無被覆壁面の 14.0\%であった。

\section{（３）事例 3 (軽量鉄骨造）の場合（西側壁面）}

南側の壁面 (2 階) と西側の壁面（1 階）で計測を行ったが, 南側の壁面は屋内側の壁が老朽化しており手で触れると砂壁がボ ロボロと落ちる状態であり, 熱流計測板を壁面に密着させること ができなかったため, 採取した熱流のデータは非常に不安定な数 值であった。そのため, 西面での計測デー夕のみを分析の対象之 した。壁面の構造は, 外側がコンクリート系ボード, 軽量鉄骨の 空隙を挟んで内側が化粧合板である。

1995 年 8 月 24 日（木）（晴天日） $19 ： 00$ から 8 月 26 日（土） $19: 00$ までの 48 時間の西側壁面での熱流（45 cm離れた上下 2 点 での計測データの平均值。冷房あり）の経時変化をグラフで示す と図 5 のと抽であった。

壁面から屋内への熱流は無被覆壁面では 8 月 25 日には $16: 00$ に最高值 $22.01 \mathrm{~W} / \mathrm{m}^{2}$ を記録した。つる植物（斑入りセイヨウキ ヅタ）が厚く被覆した緑化壁面での熱流は 8 月 25 日 16：00 には $4.40 \mathrm{~W} / \mathrm{m}^{2}$ であり, 無被覆壁面の $20.0 \%$ \%あった。また, つる植 物の被覆があまり厚くない緑化壁面での熱流は 8 月 25 日 $16: 00$ には $8.45 \mathrm{~W} / \mathrm{m}^{2}$ あ゙あ，無被覆壁面の $38.4 \%$ であた。

熱流を積算した熱流量は，屋内側への流入熱量のみについて 8 月 25 日 5：00から 8 月 26 日 5：00 までの 24 時間值を見ると,
無被覆壁面では $448.13 \mathrm{KJ} / \mathrm{m}^{2}$ であったが，厚く 被覆した緑化壁面では $102.82 \mathrm{KJ} / \mathrm{m}^{2}$ であり，無 被覆壁面の $22.9 \%$ であった。また, つる植物の 被覆があまり厚くない緑化壁面では $182.61 \mathrm{KJ} /$ mであり，無被覆壁面の 40.7\%であった。

\section{4. まとめ}

以上の結果をとりまとめると表 7 のと抢りで ある。結論として以下のことが明らかとなった。 (1)屋内への熱の流入は壁面緑化により大きく抑 制される。

壁面緑化による夏季の屋内への熱の流入抑制 効果が大きいことが数值で示された。すなわち, 無被覆壁面での屋内への熱流のピーク值に対し, 同じ時刻の緑化壁面での屋内への熱流は 84.51 〜 $13.56 \mathrm{~W} / \mathrm{m}^{2}$ 減少しているというデータが得ら れた。これを建築構造別にみると, 〔屋内で冷 房を稼働させたプレハブ造〕で最大の $84.51 \mathrm{~W}$ $/ \mathrm{m}^{2}$ 減少し, 次いで〔晴天日のプレハブ造〕, 〔曇天日のプレハブ造〕，鉄筋コンクリート造〕, 〔厚く壁面緑化した簡易鉄骨造〕，〔やや厚く壁 面緑化した簡易鉄骨造】の順之なっている。簡 易鉄骨造では対象が西側壁面であり，午後にな らないと無被覆壁面が熱くならないため, 冷房 が稼働していたにもかかわらず，無被覆壁面で のピーク時の屋内への熱流が $22.01 \mathrm{~W} / \mathrm{m}^{2}$ でし かなった。このことから，簡易鉄骨造で屋内へ の熱流が他の事例の場合より小さい傾向を示し たことは理解できる。また，無被覆壁面での屋 内への 24 時間の積算熱流量が壁面緑化により $1,186.79 \mathrm{KJ} / \mathrm{m}^{2} \sim 265.52 \mathrm{KJ} / \mathrm{m}^{2}$ 削減されるとい うデー夕が得られた。これを建築構造別にみる と, 〔屋内で冷房を稼働させたプレハブ造〕, 〔晴天日のプレハブ造〕，鉄筋コンクリート造〕，〔曇天日のプレ 八ブ造〕，〔厚く壁面緑化した簡易鉄骨造〕〔やや厚く壁面緑化し た簡易鉄骨造〕の順に削減量が大きかった。ピーク時の屋内への 熱流の削減量の順位と比べると，〔曇天日のプレハブ造〕と〔鉄 筋コンクリート造〕とで順位が入れ替わっているが，これは，鉄 筋コンクリート造の壁面は熱容量が大きいため，ピーク時を過ぎ ても屋内への熱流が比較的大きい状態が続くことで説明できる。 (2)冷房を稼働させると屋内に流入する熱の削減量が大きくなる。 冷房が稼働すると室内の気温が低下するために屋外からの熱の流 入が大きくなる。緑化壁面であっても屋内への熱の流入が大きく なるが, 無被覆壁面ではそれょりも多く熱が流入する。そのため, 冷房を稼働させている場合の方が，冷房が稼働していない場合よ り, 壁面緑化による屋内への熱の流入の削減量は, 大きくなる。 （図 3 を図 1 や図 2 と比較するとわかる。）(3)鉄筋コンクリート造 の無被覆壁面では屋内への大きな熱流が長く続く。鉄筋コンクリー 卜造の建築物の場合, コンクリートの比熱が大きいため, 屋内へ の熱の流入量は, 無被覆壁面でも緑化壁面でも, 他の簡単な構造 の壁面の建築物の場合よりも小さい。しかし, 無被覆壁面の場合, 一旦壁体の温度が高くなると, 外気の気温が下がって熱の屋外へ の放射が始まっても容易には温度が下がらず，夜遅くまで屋内に 熱を放出し続ける。しかし壁面緑化により, 屋内への熱の流入は ほとんどゼロに近いくらいに小さくなる。(図 4 を図 1 や図 2 と 比較するとわかる。）(4)壁面緑化による冷房用電力使用料金の削 減額はそれほど大きくはない。表 7 より, 建築物の屋内への熱の 流入の抑制量は, 事例 1 で冷房を稼働させた場合が最む大きく, 
表－７壁面緑化による夏季の壁面から屋内への熱流および熱流量の削減量の総括表

\begin{tabular}{|c|c|c|c|c|c|c|c|c|c|c|}
\hline $\begin{array}{l}\text { 場所。 } \\
\text { 建物の構 } \\
\text { 造 }\end{array}$ & 計測日時 & $\begin{array}{l}\text { 壁面の } \\
\text { 向き }\end{array}$ & 冷房 & $\begin{array}{l}\text { つる植物 } \\
\text { の種類 }\end{array}$ & $\begin{array}{l}\text { 被覆の } \\
\text { 程度 (葉 } \\
\text { 面積指 } \\
\text { 数) }\end{array}$ & $\begin{array}{l}\text { 熱流 }(\text { 壁面 } \rightarrow \\
\text { 室内。W/m2) } \\
<>\text { 内無被 } \\
\text { 覆壁面での值 } \\
\text { との差 }\end{array}$ & $\begin{array}{l}\text { 左の } \\
\text { 計測 } \\
\text { 時刻 }\end{array}$ & $\begin{array}{l}\text { 無被覆壁 } \\
\text { 面での最 } \\
\text { 大值に対 } \\
\text { する比率 } \\
\text { (\%) }\end{array}$ & $\begin{array}{l}24 \text { 時間の熱流量 } \\
\text { (KJ/m2) } \\
<<>\text { 内無被 } \\
\text { 覆壁面での值と } \\
\text { の差 }\end{array}$ & $\begin{array}{l}\text { 無被覆壁 } \\
\text { 面での熱 } \\
\text { 流量に対 } \\
\text { する比率 } \\
\text { (\%) }\end{array}$ \\
\hline \multirow{6}{*}{$\begin{array}{l}\text { 茨城県つ } \\
\text { くば市。 } \\
\text { プレハブ } \\
\text { 造 }\end{array}$} & \multirow[t]{2}{*}{$\begin{array}{l}\text { 1992/7/30〜 } \\
31 \text { (晴天日) }\end{array}$} & \multirow[t]{2}{*}{ 南 } & \multirow[t]{2}{*}{ なし } & - & $\begin{array}{l}\text { 無被覆 } \\
\end{array}$ & $\begin{array}{l}\text { 最大值 } \\
44.01\end{array}$ & $\begin{array}{l}7 / 30 \\
10: 40\end{array}$ & 100.0 & 858.57 & 100.0 \\
\hline & & & & $\begin{array}{l}\text { テイカカ } \\
\text { ズラ }\end{array}$ & 約 2.3 & $\begin{array}{l}9.15 \\
<\triangle 34.86>\end{array}$ & 同上 & 20.8 & $\begin{array}{l}219.88 \\
<\triangle 638.69>\end{array}$ & 25.6 \\
\hline & \multirow{2}{*}{$\begin{array}{l}1992 / 8 / 4 \\
\sim \text { (曇天日) }\end{array}$} & \multirow[t]{2}{*}{ 南 } & \multirow[t]{2}{*}{ なし } & - & $\begin{array}{l}\text { 無被覆 } \\
\end{array}$ & $\begin{array}{l}\text { 最大值 } \\
38.73 \\
\end{array}$ & $\begin{array}{l}8 / 4 \\
12: 00\end{array}$ & 100.0 & 499.85 & 100.0 \\
\hline & & & & $\begin{array}{l}\text { テイカカ } \\
\text { ズラ }\end{array}$ & 約 2.3 & $\begin{array}{l}6.16 \\
<\triangle 32.57>\end{array}$ & 同上 & 15.9 & $\begin{array}{l}67.78 \\
<\triangle 432.07>\end{array}$ & 13.6 \\
\hline & \multirow[t]{2}{*}{$\begin{array}{l}1992 / 8 / 18 \sim \\
19 \text { (晴天日) }\end{array}$} & \multirow[t]{2}{*}{ 南 } & \multirow[t]{2}{*}{ あり } & - & $\begin{array}{l}\text { 無被覆 } \\
\end{array}$ & $\begin{array}{l}\text { 最大值 } \\
102.29\end{array}$ & $\begin{array}{l}8 / 18 \\
11: 40\end{array}$ & 100.0 & $1,999.77$ & 100.0 \\
\hline & & & & $\begin{array}{l}\text { テイカカ } \\
\text { ズラ }\end{array}$ & 約 2.3 & $\begin{array}{l}17.78 \\
<\triangle 84.51>\end{array}$ & 同上 & 17.4 & $\begin{array}{l}812.98 \\
<\triangle 1186.79>\end{array}$ & 40.7 \\
\hline \multirow{2}{*}{$\begin{array}{l}\text { 東京都文 } \\
\text { 京区。鉄 } \\
\text { 笳コンク } \\
\text { リート造 }\end{array}$} & \multirow[t]{2}{*}{$\begin{array}{l}\text { 1992/8/14〜 } \\
15 \text { (晴天日) }\end{array}$} & \multirow[t]{2}{*}{ 南 } & \multirow[t]{2}{*}{ なし } & - & $\begin{array}{l}\text { 無被覆 } \\
\end{array}$ & $\begin{array}{l}\text { 最大值 } \\
26.40 \\
\end{array}$ & $\begin{array}{l}8 / 14 \\
13: 20 \\
\end{array}$ & 100.0 & 715.90 & 100.0 \\
\hline & & & & ナツヅタ & $\begin{array}{l}\text { 約 } 2.3 \\
\text { とみなす }\end{array}$ & $\begin{array}{l}1.05 \\
<\triangle 25.35>\end{array}$ & 同上 & 4.0 & $\begin{array}{l}100.54 \\
<\triangle 615.36>\end{array}$ & 14.0 \\
\hline \multirow{3}{*}{$\begin{array}{l}\text { 茨城県 } \\
\text { 取手市。 } \\
\text { 軽量鉄骨 } \\
\text { 造 }\end{array}$} & \multirow[t]{3}{*}{$\begin{array}{l}\text { 1995/8/24〜 } \\
26 \text { (晴天日) }\end{array}$} & \multirow[t]{3}{*}{ 西 } & \multirow[t]{3}{*}{ あり } & - & 無被覆 & $\begin{array}{l}\text { 最大值 } \\
22.01 \\
\end{array}$ & $\begin{array}{l}8 / 25 \\
16: 00\end{array}$ & 100.0 & $\begin{array}{l}8 / 255: 00 \sim \\
448.13\end{array}$ & 100.0 \\
\hline & & & & $\begin{array}{l}\text { 斑入りセ } \\
\text { イョウキ } \\
\text { ジタ }\end{array}$ & 3.94 & $\begin{array}{l}4.40 \\
<\triangle 17.61>\end{array}$ & 同上 & 20.0 & $\begin{array}{l}\text { 同上 } \\
102.82 \\
<\triangle 345.31>\end{array}$ & 22.9 \\
\hline & & & & $\begin{array}{l}\text { 斑入りセ } \\
\text { イョウキ } \\
\text { ヅタ } \\
\end{array}$ & 2.88 & $\begin{array}{l}8.45 \\
<\triangle 13.56>\end{array}$ & 同上 & 38.4 & $\begin{array}{l}\text { 同上 } \\
182.61 \\
<\triangle 265.52>\end{array}$ & 40.7 \\
\hline
\end{tabular}

24 時間の積算熱流量の削減量は $1186.79 \mathrm{KJ} / \mathrm{m}^{2}$ である。この熱を 冷房装置によって排出するために必要な電力量は, 冷房装置の電 力使用率を 0.4 とすると， $0.132 \mathrm{kWh}$ となる $(1186.79 \mathrm{KJ} \times 0.4 \div$ 60 秒 $\div 60$ 秒)。 $1 \mathrm{kWh}$ の電力使用料金を 16.15 円とすると, こ の壁面緑化による熱の流入抑制効果を電力使用料金で表すと, こ の日 24 時間で $1 \mathrm{~m}^{2}$ あり約 2.13 円となる。

同様の計算により，〔晴天日のプレハブ造〕では 1.15 円，〔鉄 筋コンクリート造〕では 1.10 円，〔曇天日のプレハブ造〕では 0.78 円，〔厚く壁面緑化した簡易鉄骨造〕では 0.62 円，〔やや厚 く壁面緑化した簡易鉄骨造】では 0.48 円となる。

ただし，金額的にはそれほど大きくなくとも，屋内への熱の流入 の 24 時間積算値が 13.6〜 40.7\%に減少するということは大きな 効果であり, 身体感覚的にも意義は大きい。今後, 他の各種の効 果も数値として把握し, 総合的に壁面緑化の効果を数值化してい くことが求められる。

\section{参考文献}

1 ) 梅干野晃・茶谷正洋・八木幸二（1985）：ッ夕の西日遮へい 効果に関する実験研究：日本建築学会計画系論文報告集第 351 号, 11-19

2 ) 松井民憲（1990）：植物を利用した省エネルギー：緑の読本 シリーズ 14，31-39

3 ）ピチャクム ナース・丸田頼一（1992）：夏季の気温と日射に 対する建築物壁面の緑化の効果に関する研究 : 環境情報科学 $21-2, \quad 54-60$

4 ) 冲中健・本田淳一・物部良紀（1986）：ナッッ゙夕の初期生長 に関する研究 一壁面緑化に扮いて一: 千葉大学園芸学部学 術報告第 38 号, 87-92

5 ) 冲中健・朴容珍（1987）：主要な壁面登攀性つる植物の初期 生長に関する研究：造園雑誌 50(5), 90-95

6 ) 冲中健・山内啓治・藤井英二郎（1988）：ナッッ゙夕の壁面付
着に関する数種の条件について：造園雑誌 51(5)，102-107

7 ) 朴容珍・冲中健（1990）：壁面緑化用つる植物の登攀之下垂 に打ける生育特性に関する基礎的研究：造園雑誌 53(5), 115-120

8 ) 冲中健・山内啓治・朴容珍（1991）：種々の粗さの壁面に対 するナッヅ夕付着盤の付着：千葉大学園芸学部学術報告第 44 号, 245-254

9 ) Johnston Jacklyn (1992) : Building Green : a guide to using plants on roofs, walls and pavements, London : L ondon Ecology Unit, p.59

10) Steemers Koen (1998): Radiation absorption and urban $t$ exture : Building Research \& Information 26(2), pp.103112

11) G. Papadakis (2002) : An experimental investigation of the effect of shading with plants for solar control of buil dings : Energy and Buildings 33, pp.831-836

12) Chen Yu (2002): AN INVESTIGATION OF THE EFFECT OF SHADING WITH VERTICAL LANDSCAPING IN SINGAPORER : Proceedings of IFPRA (International Federation of Park and Recreation Administration) AsiaPacific Congress 2002 SINGAPORE (CD-ROM)内に収録, p.9

13）野島義照 - 冲中健 - 小林達明 - 坊垣和明 - 瀬戸裕直 - 倉山千 春（1993）：壁面緑化による建築物の壁面温度の上昇抑止効 果の実証的研究：造園雑誌 56(5)，115-120

14）冲中健・野島義照・小林達明・瀬戸裕直（1994）：つる植物 の被覆がコンクリート建物の壁面温度に及ぼす効果 : 千葉大 学園芸学部学術報告第 48 号, 125-134

15）野島義照（1998）：都市における植生からの蒸散による夏期 の温熱環境改善力に関する研究（博士論文）：自費出版, p.181 